\title{
Peningkatan Kualitas Kebijakan Publik bagi Anggota DPRD dan Aparatur Sipil Negara di Wilayah Bandung Raya
}

\author{
Titin Rohayatin, Agustina Setiawan, Noer Apptika, Bayu Septiansyah \\ Prodi Ilmu Pemerintahan, Fakultas Ilmu Sosial dan Ilmu Politik, \\ Universitas Jenderal Achmad Yani \\ Penulis korespondensi : titin.rohayatin@lecture.unjani.ac.id
}

\begin{abstract}
Abstrak: Saat ini pemahaman terhadap serangkaian proses kebijakan khususnya di tataran pemerintah daerah masih dirasakan kurang, baik pemahaman dalam pengenalan jenis kebijakan, proses pembuatan kebijakan maupun mengendalikan pelaksanaan kebijakan serta pemahaman dalam melakukan kerja sama antara pemerintah daerah dengan luar negeri. Perlu disadari kualitas masyarakat di daerah ditentukan oleh kebijakan publik di daerah, mulai dari peraturan daerah hingga keputusan Satuan Kerja Perangkat Daerah (SKPD), Camat, hingga kebijakan di tingkat kelurahan dan desa. Dengan masih kurangnya pemahaman yang dimiliki oleh pelaksana pemerintahan di daerah, perlu diselenggarakan pendidikan dan pelatihan bagi anggota dan sekretariat DPRD dan ASN daerah kabupaten atau kota. Metode pengabdian kepada masyarakat berupa diskusi, webinar, coaching, tutorial, pendampingan terkait tips dan strategi melakukan kerja sama Pemda dengan luar negeri, serta proses pembuatan bebijakan. Hasil kegiatan tersebut menunjukkan bahwa peserta memperoleh pemahaman dan wawasan yang luas terkait kerja sama Pemda dengan luar negeri serta peserta dapat mengenali kebijakan pada tingkat daerah, dapat merumuskan draft naskah akademik, merumuskan konsep Raperda, dan merumuskan konsep Perda sebagai produk dari kebijakan di tingkat daerah.
\end{abstract}

Kata kunci: Peningkatan Kualitas, Kebijakan Publik, DPRD, ASN

Abstract: Recently, the lack of the understanding of the series of policy processes especially at the regional government level still exists particularly in understanding the introduction of policy types, the process of making policies and the control of the implementation of policies as well as understanding in conducting cooperation between local and international government. It needs to be realized that the quality of the community in the certain region is determined by public policies in the region itself, such as the Regional Regulations to the Decrees of Regional Work Units, the Sub-district Head, and the policies used in a certain urban village. Realizing this fact, it is necessary to organize Education and Training for members and the secretariat of the DPRD and ASN in the Regency / City area. The community empowerment activities include focus group discussion, webinars, coaching, tutorials, assistance related to tips and strategies for conducting Regional Government Cooperation with Overseas and Policy Making Process. The results of such activities shows that participants have a broad understanding and insight related to local government and international cooperation and participants can recognize policies at the regional level, participants can formulate academic scripts, formulate the Local Government Regulations draft, and formulate the concept of Local Government Regulations as a product of policies at the regional level.

Keywords: Quality Improvement, Public Policy, DPRD, ASN 


\section{Pendahuluan}

Dewasa ini baik Pemerintah Pusat maupun Pemerintah Daerah harus dapat mengatasi masalah publik yaitu nilai, kebutuhan atau peluang yang tidak dapat terwujudkan. Seringkali masalah tersebut dapat diidentifikasi dengan baik akan tetapi hal ini dapat dicapai hanya lewat tindakan publik yaitu diantaranya melalui kebijakan publik, (Dunn, 2013: 58). Karakteristik masalah publik yang harus diatasi selain bersifat interdependensi (berketergantungan) juga bersifat dinamis (fleksibel), sehingga pemecahan masalahnya memerlukan pendekatan holistik (holistic approach) yaitu pendekatan yang memandang masalah sebagai kegiatan dari keseluruhan yang tidak dapat dipisahkan atau diukur dengan cara terpisah dari faktor lainnya. (Wahab, 2017: 38). Untuk itu, diperlukan kebijakan publik sebagai instrumen atau indikator pencapaian tujuan pemerintah baik dalam tataran Pemerintah Pusat maupun Pemerintah Daerah. (Winarno, 2012: 28).

Terkait dengan konteks pencapaian pemecahan masalah publik, Anderson (dalam Tachjan 2006: 19) menerangkan bahwa kebijakan publik merupakan serangkaian kegiatan yang mempunyai maksud dan tujuan tertentu yang diikuti dan dilaksanakan oleh seorang aktor atau beberapa/sekelompok aktor yang berhubungan dengan suatu permasalahan atau suatu hal yang diperhatikan. Seiring dengan pendapat tersebut (Nugroho 2013: 52) menjelaskan bahwa kebijakan publik berdasarkan usaha-usaha pencapaian tujuan nasional suatu bangsa dapat dipahami sebagai aktivitas/kegiatan yang dikerjakan untuk mencapai tujuan nasional dan keterukurannya dapat disederhanakan dengan mengetahui sejauh mana kemajuan pencapaian cita-cita yang telah ditempuh tersebut. Setiap kebijakan publik mempunyai tujuan baik tujuan yang berorientasi kepada pencapaian tujuan maupun yang berorientasi kepada pemecahan masalah ataupun kombinasi dari keduanya. Dalam hal ini secara singkat Agustino (2016) menjelaskan tentang tujuan kebijakan publik adalah dapat diperolehnya nilai-nilai oleh publik baik yang bertalian dengan public goods (barang publik) maupun public service (jasa publik). Nilai-nilai tersebut sangat dibutuhkan oleh publik untuk meningkatkan kualitas hidup baik secara fisik maupun secara nonfisik.

Kondisi saat ini pemahaman terhadap serangkaian proses kebijakan khususnya di tataran Pemerintah Daerah masih dirasakan kurang baik pemahaman dalam pengenalan jenis-jenis kebijakan di tingkat daerah, pemahaman dalam proses pembuatan kebijakan di tingkat daerah yang berhasil maupun pemahaman dalam mengendalikan pelaksanaan di tingkat daerah masih 
kurang. Perlu disadari kualitas masyarakat di daerah ditentukan oleh kebijakan-kebijakan publik di daerah, mulai dari Peraturan Daerah hingga Keputusan Satuan Kerja Perangkat Daerah (SKPD) atau Organisasi Perangkat Daerah (OPD), Camat, hingga kebijakan di tingkat Kelurahan dan Desa. Dengan masih kurangnya pemahaman yang dimiliki oleh pelaksana Pemerintahan di tingkat Daerah maka dosen-dosen di lingkungan Jurusan Ilmu Pemerintahan Fakultas Ilmu Sosial dan Ilmu Politik Universitas Achmad Yani Cimahi, bermaksud untuk menyelenggarakan Pendidikan dan Pelatihan bagi para anggota DPRD dan ASN daerah Kabupaten/ Kota di Wilayah Bandung Raya Provinsi Jawa Barat dalam rangka meningkatkan kapasitas kualitas kebijakan publik di daerah Jawa Barat. Alasan Menyelenggarakan, Pendidikan dan pelatihan serta pendampingan untuk dapat meningkatkan kualitas para ASN dan Anggota DPRD dalam pemahaman jenis-jenis kebijakan, pemahaman dalam proses pembuatan kebijakan dan pemahaman dalam implementasi dan pengendalian kebijakan publik di daerah.

\section{Metode}

Untuk mengukur keberhasilan Pendidikan dan pelatihan Peningkatan Kualitas Kebijakan Publik bagi para Anggota DPRD dan para Aparatur Sipil Negara tingkat Pemerintah Daerah, melalui pendekatan sebagai berikut:

a. Focus Group Discussion (FGD), mendiskusikan terkait Kerjasama Pemerintah Daerah dengan Luar Negeri dilihat dari aspek Hukum Internasional, tips dan strategi proses pembuatan kebijakan publik yang berkualitas

b. Pemberian materi dalam bentuk Webinar tentang Kerjasama Pemerintah Daerah dengan Luar Negeri dilihat dari Aspek Hukum Internasional, mengenal kebijakan publik di tingkat daerah, menguasai proses pembuatan kebijakan publik daerah yang berhasil dan mengendalikan pelaksanaan/ implementasi kebijakan publik.

c. Coaching atau tutorial dan Pendampingan Proses Pembuatan Kebijakan di tingkat daerah dari mulai Tips dan Strategi pembuatan Naskah Akademik, perumusan Raperda dan perumusan Perda sebagai Produk Kebijakan Pemerintah Daerah.

Beberapa pihak yang terlibat dalam kegiatan ini

a. Nara Sumber dari Pakar Hukum Internasional dan Pakar Analisis Kebijakan Nasional 
b. Para ASN, Anggota DPRD dan Sekretariat DPRD Kabupaten/ Kota Wilayah Bandung Raya, Purwakarta, Cianjur, Sumedang dan Kabupaten Garut Provinsi Jawa Barat.

c. Peserta webinar di luar Provinsi Jawa Barat seperti dari Kemendagri, Sekretariat DPR RI, Bawaslu Pusat, beberapa ASN dan Anggota DPRD di luar Propinsi Jawa Barat.

Keseluruhan Peserta Webinar berjumlah 377 orang, 256 diantaranya diikuti oleh Anggota DPRD, Sekretariat DPRD dan ASN di lingkungan Kabupaten Kota Di Wilayah Jawa Barat dan sisanya 121 orang peserta yang berasal dari Kabupaten/ Kota di Luar Jawa Barat.

Tempat dan waktu kegiatan Webinar baik secara Online/ Daring maupun secara Luring, berada pada tempat masing-masing yang terintegrasi dengan Host yang diselenggarakan pada Ruang Multimedia Lantai 3 Gedung TNI Mulyono FISIP Unjani.

Adapun waktu proses kegiatan Pengabdian Masyarakat dari mulai persiapan, FGD, Webinar, Coaching dan Pendampingan sampai menghasilkan draft Naskah Akademik dilakukan selama 4 bulan yaitu mulai dari bulan Agustus Tahun 2020 sampai dengan bulan November 2020.

\section{Hasil dan Diskusi}

Berbagai bentuk atau tahapan kegiatan yang dilakukan dalam kegiatan Pengabdian Pada Masyarakat (PPM) ini, hasil kegiatan PPM menunjukkan sebagai berikut:

1. Tahapan Focus Group Discussion (FGD) memberikan pemahaman tentang perlunya mengadakan Kerjasama Pemerintah dengan luar negeri untuk dapat meningkatkan Peningkatan Asli Daerah (PAD) itu sendiri. Memberikan tips dan strategi secara cepat pembuatan Draft Naskah Akademik (NA), mengenalkan jenis-jenis kebijakan Pemerintah Daerah, memberikan pemahaman terhadap kebijakan-kebijakan Pemerintah Daerah, memberikan tips dan strategi tentang proses pembuatan Rancangan Peraturan Daerah, Tips dan Strategi Pembuatan Peraturan Daerah serta cara menguasai, mengimplementasikan serta mengendalikan kebijakan Pemerintah Daerah.

2. Tahapan Webinar. Dalam tahap ini merupakan tahapan pemberian materi yang terbagi atas:

a. Materi Kerjasama Pemerintah Daerah dengan Luar negeri Dalam Perspektif Hukum Internasional, alasan kenapa Pemerintah Daerah melakukan Kerjasama dengan Luar Negeri, tips dan strategi memilih Pemerintah Daerah di Luar Negeri, tahapan 
melakukan Kerjasama dengan Luar negeri, Perjanjian Kerjasama bukan perjanjian internasional, hal-hal yang perlu dicermati dalam perjanjian Kerjasama.

b. Materi mengenal dan memahami kebijakan publik di tingkat daerah, memahami dan menguasai proses pembuatan kebijakan publik daerah yang berhasil dan mengendalikan pelaksanaan atau implementasi kebijakan publik.

3. Coaching atau tutorial dan Pendampingan Proses Pembuatan Kebijakan di tingkat daerah dari mulai Tips dan Strategi pembuatan Naskah Akademik (NA), perumusan Rancangan Peraturan Daerah (Raperda) dan perumusan Peraturan Daerah (Perda) sebagai Produk Kebijakan Pemerintah Daerah.

Dari berbagai bentuk atau metode yang diberikan dalam kegiatan PPM ini, alhasil mampu membantu meningkatkan kualitas dari anggota DPRD, Sekretariat DPRD dan para ASN dalam proses pemahaman kebijakan di tingkat daerah, pemahaman dalam proses pembuatan kebijakan di daerah. Sebagai tolak ukur keberhasilan peningkatan kualitas tersebut terlihat dengan adanya produk dari Naskah Akademik, Produk Draft Raperda, dan Produk Draft Perda.

Terdeskripsikan dengan jelas bahwa diskusi yang terjadi dalam kegiatan Webinar tersebut khususnya pemahaman Kerjasama Pemerintah Daerah dengan Luar Negeri, terlihat masih minimnya pengetahuan, Langkah dan strategi dalam melakukan Kerjasama Pemerintah Daerah dengan Luar Negri. Begitu juga masih terlihat minimnya pengetahuan tentang mengenali dan memahami kebijakan di tingkat daerah dan masih kurangnya pemahaman dalam proses pembuatan kebijakan di daerah. Melalui kegiatan ini diharapkan dapat meningkatkan kualitas dari para Anggota DPRD, secretariat DPRD dan ASN dalam pemahaman proses melakukan Kerjasama Pemda dengan Luar Negeri, pemahaman terhadap kebijakan di tingkat daerah dan pemahaman dalam proses pembuatan serta implementasi kebijakan Pemerintah di tingkat Daerah.

\section{Kesimpulan}

Melalui kegiatan pengabdian masyarakat ini dapat membantu memberikan pemahaman, wawasan yang luas serta dapat membantu meningkatkan kualitas para anggota DPRD, Sekretariat DPRD dan para ASN di daerah dalam proses tahapan melakukan Kerjasama Pemerintah Daerah dengan pihak Luar Negeri dalam Perspektif Hukum Internasional serta peningkatan kualitas dalam proses pembuatan kebijakan di tingkat daerah.

Rekomendasi untuk tindak lanjut dari kegiatan pengabdian masyarakat ini mencakup : 
a. Para anggota DPRD, sekretariat DPRD dan para ASN di daerah diharapkan dapat mengimplementasikannya di daerah masing-masing untuk dapat melakukan Kerjasama Pemerintah Daerah dengan luar negeri dalam rangka Peningkatan Pendapatan Asli Daerah masing-masing.

b. Para anggota DPRD, sekretariat DPRD dan para ASN di daerah diharapkan dapat mengaktualisasikan secara benar dalam mengenali dan memahami kebijakan tingkat daerah, dapat merumuskan Naskah Akademik, merumuskan Draft Raperda, dan Merumuskan konsep Perda serta dapat mengimplementasikan kebijakan-kebijakan di tingkat daerah.

\section{Ucapan Terima Kasih}

Ucapan terima kasih disampaikan kepada Rektor Unjani, Kepala LPPM Unjani, dan narasumber yang telah membagi ilmunya dalam kegiatan pengabdian kepada masyarakat serta para peserta yang berasal dari Kemendagri, Bawaslu Pusat, Sekretariat DPR RI, para anggota DPRD, sekretariat DPRD, para ASN baik di Kabupaten dan Kota yang berada di Wilayah Jawa Barat maupun di luar Jawa Barat, para tenaga pendidik dan tenaga kependidikan di lingkungan FISIP Unjani.

\section{Daftar Referensi}

Agustino, L. 2016. Dasar-dasar Kebijakan Publik, Alfabeta, Bandung.

Dunn, W.N. 2013. Pengantar Analisis Kebijakan Publik. Gajah Mada University Press, Yogyakarta.

Nugroho, R. 2013. Public Policy. PT Elex Media Komputindo, Jakarta.

Tachjan. 2006. Implementasi Kebijakan Publik. AIPI, Bandung.

Wahab, S.A. 2017. Analisis Kebijakan dari formulasi ke Penyusunan Model-model Implementasi Kebijakan Publik. PT Bumi Aksara, Jakarta.

Winarno, 2012. Kebijakan Publik: Teori, Proses dan Studi Kasus. CAPS, Yogyakarta. 